\title{
Effect of salinity on Brassica rapa var. toria (BRSRT) under selenium defence: A trial to assess the protective role of selenium
}

\author{
Akanksha SAO $^{1}$, Priya SARAF ${ }^{1}$, Divya BAGCHI ${ }^{2 *}$ \\ Received September 7, 2017; accepted November 24, 2017. \\ Delo je prispelo 07. septembra 2017, sprejeto 24. novembra 2017.
}

\begin{abstract}
The present study assesses the role of selenium, an antioxidant in salt-stressed plants. A hydroponic trial of sodium selenate $\left(\mathrm{Na}_{2} \mathrm{SeO}_{4}\right)$ on the growth, oxidative stress and antioxidant protection system of Brassica rapa var. toria (BRSRT) plant was studied. $40 \mu \mathrm{mol}$ and $100 \mu \mathrm{mol}$ of $\mathrm{Na}_{2} \mathrm{SeO}_{4}$ were hydroponically applied to BRSRT roots with $50 \mathrm{mmol}$ and 100 mmol sodium chloride $(\mathrm{NaCl})$ for 12 days. Plant growth, biomass production and photosynthetic pigments at $100 \mathrm{mmol}$ salt stress was inhibited while oxidative stress indicators, for example, hydrogen peroxide and lipid peroxidation were stimulated. Supplementation of $40 \mu$ mol $\mathrm{Na}_{2} \mathrm{SeO}_{4}$ with $50 \mathrm{mmol}$ and $100 \mathrm{mmol} \mathrm{NaCl}$ improved growth, photosynthetic pigments and acted as an antioxidant by inhibiting lipid peroxidation and increasing superoxide dismutase, ascorbate peroxidase, catalase, glutathione peroxidase, glutathione reductase activities. The in-gel assays also showed enhanced activities of these enzymes. At $100 \mu \mathrm{mol}$ concentration, selenium under salt stress, repressed growth and expression of antioxidant enzymes and stimulated oxidative stress with enhanced glutathione peroxidase activity. Under consolidated stress treatment, an addition of $40 \mu \mathrm{mol}$ $\mathrm{Na}_{2} \mathrm{SeO}_{4}$ was the most effective for both $\mathrm{NaCl}$ concentrations. The finding reveals that the optimal selenium supplementation presents a promising potential for use in conditions of relatively high levels of $\mathrm{NaCl}$ stress for BRSRT seedlings.
\end{abstract}

Key words: Brassica rapa; antioxidants; salinity stress; sodium selenate

\section{IZVLEČEK}

\section{UČINEK SLANOSTI NA VRSTO Brassica rapa var. toria (BRSRT) OB PRISOTNOSTI SELENA: POSKUS OVREDNOTENJA ZAŠČITNE VLOGE SELENA}

$\mathrm{V}$ raziskavi je ovrednotena vloga selena kot antioksidanta pri rastlini $\mathrm{v}$ slanostnem stresu. Vpliv natrijevega selenata $\left(\mathrm{Na}_{2} \mathrm{SeO}_{4}\right)$ na rast, oksidacijski stres in antioksidacijsko zaščito vrste Brassica rapa var. toria (BRSRT) je bil preučevan $\mathrm{v}$ hidroponskem poskusu. $40 \mu \mathrm{mol}$ in $100 \mu \mathrm{mol}$ $\mathrm{Na}_{2} \mathrm{SeO}_{4}$ je bilo 12 dni hidroponsko dodajano koreninam rastline, ki so rastle v $50 \mathrm{mmol}$ in $100 \mathrm{mmol}$ raztopini natrijevega klorida $(\mathrm{NaCl})$. Rast rastlin, produkcija biomase in vsebnost fotosinteznih pigmentov so bili zavrti pri rastlinah pod $100 \mathrm{mmol}$ solnim stresom, aktivirani pa so bili indikatorji oksidativnega stresa kot sta vodikov peroksid in peroksidacija lipidov. Dodajanje $40 \mu \mathrm{mol} \quad \mathrm{Na}_{2} \mathrm{SeO}_{4}$ pri $50 \mathrm{mmol}$ in $100 \mathrm{mmol} \mathrm{NaCl}$ je izboljšalo rast, vsebnost fotosinteznih barvil in delovalo kot antioksidant $\mathrm{z}$ inhibicijo peroksidacije lipidov in povečanjem aktivnosti superoksid dismutase, askorbat peroksidaze, katalaze, glutation peroksidaze in glutation reduktaze. Povečano aktivnost teh encimov je pokazala tudi njihova gelska anliza. Selen je pri koncentraciji $100 \mu \mathrm{mol} \mathrm{v}$ razmerah solnega stresa zavrl rast in tvorbo antioksidativnih encimov in vzpobudil oksidacijski stres $\mathrm{s}$ povečano aktivnostjo glutation peroksidaze. $\mathrm{V}$ danih stresnih obravnavanjih je bilo dodajanje $40 \mu \mathrm{mol} \mathrm{Na}_{2} \mathrm{SeO}_{4}$ najbolj učinkovito pri obeh koncentracijah $\mathrm{NaCl}$. Rezultati kažejo, da predstavlja optimalno dodajanje selena dober obet za njegovo uporabo v razmerah relativno velikega $\mathrm{NaCl}$ stresa pri sadikah obravnavane rastline.

Ključne besede: Brassica rapa; antioksidanti; slanostni stres; natrijev selenat

\footnotetext{
1 M.Sc. Biotechnology, Enzymology lab, Department of Biological Science, Rani Durgavati University, Jabalpur (Madhya Pradesh), India, P.O. Box- 482001

2 Professor, Faculty at Department of Biological Science, Rani Durgavati University, Jabalpur (Madhya Pradesh), India, P.O. Box- 482001; *Corresponding author: dbagchi_2000@yahoo.com
}

This paper is a part of the $\mathrm{PhD}$ thesis of A.S. under supervision of D.B. 


\section{INTRODUCTION}

A major challenge toward world agriculture involves production of $70 \%$ more food crop for an additional 2.3 billion people by 2050 (FAO, 2009). Up to $20-25 \%$ of the world's irrigated land, which produces one third of the world's food, is subjected to salt stress. Salinization is dispersing more rapidly in irrigated lands because of improper management of irrigation and drainage (Aliu et al., 2015). The negative effect of salt stress has been endorsed to increase in $\mathrm{Na}^{+}$and $\mathrm{Cl}^{-}$ions in diverse plants where these ions produce crucial conditions for plant survival by intercepting different plant mechanisms (Tavakkoli et al., 2010).

On the basis of adaptive evolution plants can be classified roughly into two major types: first are the halophytes that can survive in salinity and second are glycophytes that cannot survive in salinity. Majority of crop species belong to this second category. Salt stress is one of the leading abiotic stresses that affect both qualitative and quantitative behaviour of many crop species such as cabbage (Brassica oleracea L.ssp. oleracea convar. capitata (L.) Alef.), mustard (Brassica juncea L.), rapeseed (Brassica napus L. ssp. napus), and turnip rape (Brassica rapa L.). The diploid species of brassica (Brassica rapa L.) is more susceptible to salt stress then other polyploidy species (Kumar, 1995). Brassica is the third most common oil plant in the world often cultivated in arid and semiarid regions in different countries, where salt stress warns to become or already is a problem.

Salinity builds up the assembly of oxidative stress in plant cells. These reactive oxygen species (ROS) like hydroxyl radicals $\left(\mathrm{OH}^{*}\right)$, hydrogen peroxide $\left(\mathrm{H}_{2} \mathrm{O}_{2}\right)$, and superoxide radicals $\left(\mathrm{O}_{2}{ }^{-}\right)$, are involved in the degradation of membrane components, the oxidation of protein sulphydryl groups, and the loss of membrane function (Feng et al., 2013). To shield cellular membranes and organelles from the destructive effects of reactive oxygen species, plants develop various nonenzymatic and enzymatic antioxidant defence systems. Jaleel et al. (2009) reported that the non-enzymatic antioxidants include lipid soluble (e.g., $\alpha$-tocopherol and $\beta$-carotene) antioxidant, and water soluble reductants (e.g., reduced glutathione (GSH) and ascorbic acid (AsA)). Facts suggest that membranes are the principal sites of salinity damage to cells and organelles (Janmohammadi et al., 2012) because ROS can react with unsaturated fatty acids to cause peroxidation of essential membrane lipids in plasma membrane or in the membranes of organelles. The antioxidant enzymes such as ascorbate peroxidase (APX), catalase (CAT), glutathione peroxidase (GPX), glutathione reductase
(GR), peroxidase (POX), superoxide dismutase (SOD), were considered as a self-protective team, whose pooled purpose is to protect cells from oxidative damage. AsA is considered the most powerful ROS scavenger because of its ability to donate electrons in a number of enzymatic and non-enzymatic reactions. SOD catalyzes the dismutation of superoxide into $\mathrm{H}_{2} \mathrm{O}_{2}$ and $\mathrm{O}_{2}$ and is one of the most effective antioxidant enzymes in limiting oxidative damage. The physiological role of GPX is to maintain low levels of $\mathrm{H}_{2} \mathrm{O}_{2}$ within the cell, thus decreasing potential damage from free radicals. GR catalyzes the reduction of GSH, a molecule involved in many metabolic, regulatory, and antioxidative processes in plants (Apel \& Hirt, 2004).

In recent years articles have been published describing selenium (Se) as an essential element, counteracting various stress factors in animals and humans. Although it has not been confirmed to be a vital micronutrient in higher plants, there is increasing evidence that $\mathrm{Se}$ functions as an antioxidant in plants (Avila et al., 2014). Recent studies on the mitigating effect of Se on environmental stress have mostly aimed on the Semediated activation of antioxidative defense (Hajiboland et al., 2014). High Se concentration is shown to provoke oxidative stress responses. Growth stimulating effect of trace amounts of Se has been often reported in some plant species such as ryegrass (Hartikainen et al., 2000), lettuce (Xue et al., 2001), potato (Seppänen et al., 2003), soybean (Djanaguiraman et al., 2005), sorghum (Djanaguiraman et al., 2010), rice (Wang et al., 2012), and different varieties of Brassica oleracea L. (Hajiboland \& Amjad, 2007). Previous studies have indicated that adequate Se concentration can lessen the harmful impact of excessive salinity in some plant species, mainly by enhancing the antioxidant response of plants [Hawrylak-Nowak, 2009 (cucumber); Walaa et al., 2010 (cucumber); Hasanuzzaman et al., 2011 (rapeseed) ; Diao et al., 2014 (tomato)]. Brassica plants are special crops that have high potential to create and accumulate monomethylated forms of Se, such as Se-methylselenocysteine and selenomethionine (Terry et al., 2000). Se affects plants by (1) improving plant growth and defending plant against abiotic stresses (heavy metal) at low dosage, and (2) as a pro-oxidant, which is toxic to plants at high doses (Kaur et al., 2014). Therefore, the present experiment was conducted as a trial assessment to evaluate the possible protective role of $\mathrm{Se}\left(\mathrm{Na}_{2} \mathrm{SeO}_{4}\right)$ with an emphasis on enzymatic and non-enzymatic antioxidative defence response on Brassica rapa var. toria (BRSRT) plants against salt stress. 


\section{MATERIALS AND METHODS}

\subsection{Chemicals}

All reagents like sodium selenate $\left(\mathrm{Na}_{2} \mathrm{SeO}_{4}\right)$, thiobarbituric acid (TBA), reduced glutathione (GSH), oxidized glutathione (GSSG), 5,5'-dithio-bis-[2nitrobenzoic acid] (DTNB), L-cysteine, nicotinamide adenine dinucleotide (NADPH), bovine serum albumin (BSA), Baker's yeast glutathione reductase (GR), Odianisidine dihydrochloride, 3'(4,5-dimethylthiazol2yl)-2,5-diphenyltetrazolium bromide (MTT), 2,6 dichlorophenolindophenol (DCPIP) were purchased from Sigma Life Sciences (U.S.A.). Sulfosalicylic acid (SSA) was purchased from Hi-Media, India.

\subsection{Phytotron trial}

The mature seeds of Brassica rapa var. toria (BRSRT) were provided by the Directorate of Rapeseed Mustard Research (formerly, NRCRM), Sewer, Rajasthan, India. BRSRT seeds were first treated with $5 \%$ sodium hypochlorite solution for $5 \mathrm{~min}$. for surface sterilization and continuous shaking with doubled distilled water for 5-10 minutes. The seeds were then sown on the top of filter paper moistened with doubled distilled water inside the $15 \mathrm{~cm}$ plastic petri dishes. On the fifth day uniform-sized seedling were selected and transferred into hydroponic medium in the pots (one plant in each pot), which were acid-washed (2\% nitric acid). Each pot contained half strength Hoagland nutrient solution (Hoagland \& Arnon, 1950). Sodium selenate was preferred as it was one of the most effective form of Se for increasing plant growth and accumulation (Poblaciones et al., 2014) and $\mathrm{NaCl}$ was used for visualizing salinity toxicity in plants. The pots were arranged in complete randomized design.

The conditions in each phytotron were closely monitored to ensure that the four groups and nine treatments of plants grew under identical conditions, which was as follow: the first group include two treatments of $\mathrm{NaCl}(50 \mathrm{mmol}$ and $100 \mathrm{mmol})$, second group include two treatments of $\mathrm{Se}(40 \mu \mathrm{mol}$ and $100 \mu \mathrm{mol} \mathrm{Na}_{2} \mathrm{SeO}_{4}$ ), and third group include four treatment of $\mathrm{Se}$ and $\mathrm{NaCl}(50 \mathrm{~mm} \mathrm{NaCl}+40 \mu \mathrm{mol}$ $\mathrm{Na}_{2} \mathrm{SeO}_{4}, 50$ mmol $\mathrm{NaCl}+100 \mu \mathrm{mol} \mathrm{Na}_{2} \mathrm{SeO}_{4}$, $100 \mathrm{mmol} \mathrm{NaCl}+40 \mu \mathrm{mol} \mathrm{Na}_{2} \mathrm{SeO}_{4}$ and $100 \mathrm{mmol}$ $\left.\mathrm{NaCl}+100 \mu \mathrm{mol} \mathrm{Na}_{2} \mathrm{SeO}_{4}\right)$ together against fourth group of control treatment (only half strength Hoagland solution). $\mathrm{NaCl}$ was gradually added to the growth medium in five divided dose at every alternate day to avoid osmotic shock and Se was applied on third day, sixth day and when $\mathrm{NaCl}$ was added as last dose into the growth medium. The growth conditions were as follows: photoperiod of $14 / 10 \mathrm{~h}$ light/dark cycle, temperature $23 / 15{ }^{\circ} \mathrm{C}$ (day/night), $75 \%$ mean relative humidity, and the maximal photosynthetic photon flux density of $270 \mu \mathrm{mol} \mathrm{m} \mathrm{m}^{-1}$. The plants were harvested from each phytotron on $12^{\text {th }}$ day after commencement of the experiment. For each treatment, three replicates were taken for analysis.

\subsection{Stress tolerance index (STI) percentage (\%)}

Root length was considered as an indicator for stress tolerance and the ratio of average root length with Se and average root length of control was calculated. Tolerance index percentage was calculated by multiplying the obtained ratio by 100 (Pilon-Smits et al., 1999).

$\operatorname{STI}(\%)=\frac{\text { Average root length }(\mathrm{cm})+\text { Treated }(\mathrm{Se} \text { or } \mathrm{NaCl}) \quad \mathrm{X} 100 \ldots . . .(\mathrm{i})}{\text { Average root length control }(\mathrm{cm})}$

Tolerance index was also calculated for shoot length and leaf area after 12 days of plant growth under different experimental conditions.

\subsection{Chlorophyll and carotenoids content}

Chlorophyll content was estimated following Arnon (1949) method with some modifications. Fresh leaves $(100 \mathrm{mg})$ from each of the sample were homogenized in $1.5 \mathrm{ml}$ of $80 \%(\mathrm{v} / \mathrm{v})$ acetone and the reaction was incubated in dark for $1 \mathrm{~h}$ at $25^{\circ} \mathrm{C}$. The mixture was centrifuged at 10,000 $\mathrm{g}$ for $5 \mathrm{~min}$ and absorbance of the supernatant was recorded at $645 \mathrm{~nm}, 663 \mathrm{~nm}$ (for chl) and $470 \mathrm{~nm}$ (for carotenoids) against $80 \%$ acetone which served as blank. The chlorophyll and carotenoid content was determined as follows:

Chl $a\left(\mathrm{mg} \mathrm{g}^{-1} \mathrm{FM}\right)=12.7\left(\mathrm{~A}_{663}\right)-2.29\left(\mathrm{~A}_{645}\right) \times$ $($ volume $/ 1000) \times$ mass of tissue...............

Chl $b\left(\mathrm{mg} \mathrm{g}^{-1} \mathrm{FM}\right)=22.9\left(\mathrm{~A}_{645}\right)-4.68\left(\mathrm{~A}_{663}\right) \times$ $($ volume $/ 1000) \times$ mass of tissue............

Carotenoids $\left(\mathrm{mg} \mathrm{g}^{-1} \mathrm{FM}\right)=\left(1000 \mathrm{X} \mathrm{A}_{470}\right)-(1.29 \mathrm{Chl} a$ $-53.798 \mathrm{Chl} b) / 220$.

\subsection{Measurement of ROS generation}

$\mathrm{H}_{2} \mathrm{O}_{2}$ was assayed according to the method described by $\mathrm{Yu}$ et al. (2003). The optical absorption of the supernatant was measured spectrophotometrically at $410 \mathrm{~nm}$ to determine the $\mathrm{H}_{2} \mathrm{O}_{2}$ content using the extinction co-efficient of $0.28 \mu \mathrm{mol}^{-1} \mathrm{~cm}^{-1}$ and expressed as $\mu \mathrm{mol} \mathrm{g}^{-1}$ fresh mass (FM). Lipid peroxidation of leaf was estimated by the level of malondialdehyde (MDA) production using TBA method as described by Hodges et al. (1999). The supernatant $(0.5 \mathrm{ml})$ was mixed with $20 \%$ TCA $(2.5 \mathrm{~mL})$ containing $0.5 \% \mathrm{TBA}$ and heated in a boiling water bath for 30 min and immediately allowed to cool in an ice bath, the 
absorbance of the supernatant was measured at $532 \mathrm{~nm}$, with a reading at $600 \mathrm{~nm}$ subtracted from it to account for nonspecific absorption. The MDA-TBA complex was quantified using the extinction coefficient of $155 \mathrm{mmol}^{-1} \mathrm{~cm}^{-1}$ and expressed as $\mu \mathrm{mol} \mathrm{g}{ }^{-1} \mathrm{FM}$.

\subsection{Measurement of non-enzymatic antioxidant}

Leaves $(0.5 \mathrm{~g}$ FM) were homogenized in $3 \mathrm{ml}$ ice-cold acidic extraction buffer $(6 \%$ meta-phosphoric acid containing 1 mmol EDTA) using a mortar and pestle. Homogenates were centrifuged at $11,500 \times \mathrm{g}$ for $15 \mathrm{~min}$ at $4{ }^{\circ} \mathrm{C}$, and the supernatant was collected for analysis of ascorbate and glutathione while for NPT, 1:6 ratio of $5 \%$ sulfosalicylic acid (SSA) was used instead of acidic extraction buffer and the supernatant was stored at $20{ }^{\circ} \mathrm{C}$.

Ascorbic acid estimation was done by hydrazine method, according to Mukherjee \& Choudhuri (1983). The absorbance was recorded at $530 \mathrm{~nm}$. Unknown concentration of ascorbic acid was estimated by plotting standard curve with known concentration of ascorbic acid. GSH and GSSG content were determined by the recycling method according to Anderson (1985). Aliquot $(0.5 \mathrm{ml})$ was taken in a microfuge tube, to which $0.5 \mathrm{ml}$ reaction buffer (0.1 mol PBS pH 7.6), $0.5 \mathrm{mmol}$ EDTA and $50 \mu \mathrm{l}$ of $3 \mathrm{mM}$ DTNB were added in a final volume of $1.2 \mathrm{ml}$. After $5 \mathrm{~min}$, absorbance of GSH was read at $412 \mathrm{~nm}$. To the same tube $100 \mu \mathrm{l}$ of NADPH $(0.4 \mathrm{mmol})$ and $2 \mu \mathrm{l} \mathrm{GR}$ was added for the determination of total glutathione; the reaction was allowed to run for $20 \mathrm{~min}$. The amount of GSSG was calculated by subtracting GSH from total glutathione concentrations. A standard curve was prepared with varying concentration of reduced glutathione. NPT assay, were done according to method described by Israr et al. (2006). Absorbance were taken twice, initial absorbance was recorded at $412 \mathrm{~nm}$ while final absorbance recorded after addition of $300 \mu \mathrm{l}$ DTNB solution (6 mmol DTNB dissolved in 5 mmol EDTA in reaction buffer PBS pH 7.6). Strength of NPT content in the sample was calculated by L-cysteine standard curve.

\subsection{Measurement of enzymatic antioxidant}

Fresh leaves $(1 \mathrm{~g})$ were homogenized in $1.5 \mathrm{ml}$ of chilled reaction buffer (100 mmol potassium phosphate buffer $\mathrm{pH} 7.0,1 \mathrm{mmol}$ EDTA and $1 \%(\mathrm{w} / \mathrm{v})$ PVP) in precooled mortar. The homogenate was filtered and then centrifuged (pre-cooled) at $10,000 \mathrm{x} \mathrm{g}$ for $20 \mathrm{~min}$. Experiments were done at $4{ }^{\circ} \mathrm{C}$, supernatant collected and stored at $-20{ }^{\circ} \mathrm{C}$ for further enzyme assay. Total protein concentration of antioxidative enzymes was assayed according to Lowry et al. (1951) using BSA (bovine serum albumin) as standard and specific activity

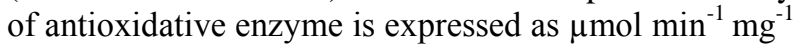
protein.
The SOD (EC 1.15.1.1) activity was monitored by its ability to inhibit the photochemical reduction of nitroblue tetrazolium (NBT). One unit of SOD was defined as the amount of enzyme necessary to cause $50 \%$ inhibition of the rate of NBT reduction at $560 \mathrm{~nm}$. The reaction mixture was placed on a shaker under light at $80 \mu \mathrm{mol}$ photons $\mathrm{s}^{-1} \mathrm{~m}^{-1}$ for $15 \mathrm{~min}$ and absorbance was recorded. A non-irradiated reaction mixture that did not develop colour served as the control and its absorbance was subtracted from $\mathrm{A}_{560}$ of the reaction solution (Giannopolitis \& Ries, 1977). CAT (EC 1.11.1.6) activity was monitored by measuring the reduction in absorbance due to consumption of $\mathrm{H}_{2} \mathrm{O}_{2}$ at $240 \mathrm{~nm}$ (Aebi, 1984). The reaction was initiated with enzyme extract and the activity was calculated using the extinction co-efficient of $39.4 \mathrm{~mol}^{-1} \mathrm{~cm}^{-1}$. APX (EC 1.11.1.11) activity was determined following the method of Nakano and Asada (1981). The enzyme activity was measured by observing the decrease in absorbance at $290 \mathrm{~nm}$ for 1 min using the extinction coefficient of $2.8 \mathrm{mmol}^{-1} \mathrm{~cm}^{-1}$. GPX (EC 1.11.1.9) activity was measured as described by Elia et al. (2003) with minor modification. The oxidation of NADPH was observed at $340 \mathrm{~nm}$ for $1 \mathrm{~min}$ and the enzyme assay activity was calculated using the extinction co-efficient of $6.62 \mathrm{mmol}^{-1} \mathrm{~cm}^{-1}$. GR (EC 1.6.4.2) activity was assayed according to the method of Cakmak et al. (1993). The reaction was started with oxidized GSH and the reduction in absorbance at $340 \mathrm{~nm}$ due to NADPH oxidation was recorded for $1 \mathrm{~min}$. The activity was calculated using extinction co-efficient of $6.2 \mathrm{mmol}^{-1}$ $\mathrm{cm}^{-1}$.

\subsection{Activity staining of antioxidant enzymes}

In-gel assays was performed to visualize the change in enzyme activities of the extracts from the control, $\mathrm{NaCl}$ treated and $\mathrm{Se}$ induced plants by One-dimensional Native-PAGE according to the method of Lammeli (1970). The amount of protein in supernatant was measured according to Lowry et al. (1951). Hundred $\mu \mathrm{g}$ protein equivalents were loaded in the gel. NativePAGE After the run, the gels was zymographed for the presence of the oligomeric form as follows.

Activity staining for SOD was carried out following the method of Yen et al. (1996). The gel was equilibrated in $50 \mathrm{mmol} \mathrm{K}-\mathrm{PO}_{4}$ buffer $\mathrm{pH} 7.8$ containing $2.3 \mathrm{mmol}$ NBT, $0.028 \mathrm{mmol}$ riboflavin and $280 \mathrm{mmol}$ TEMED for 15 min in dark. The gel was washed twice with distilled water and illuminated in light until achromatic bands appeared against purple-background. CAT activity was determined by pre incubating the gel in $3.27 \mathrm{mmol} \mathrm{H}_{2} \mathrm{O}_{2}$ for $25 \mathrm{~min}$, rinsed in distilled water and stained in solution of $1 \% \mathrm{FeCl}_{3}$ and $\mathrm{K}_{3} \mathrm{Fe}[\mathrm{CN}]_{6}$ until achromatic bands on a Prussian blue background appeared (Woodbury et al., 1971). POX activity was detected by 
incubating the gel in $50 \mathrm{mmol} \mathrm{NaPO}_{4}$ buffer $\mathrm{pH} 7.0$ containing $2 \mathrm{mmol}$ ascorbate for $15 \mathrm{~min}$ and further incubation for $20 \mathrm{~min}$ in presence of $4 \mathrm{mmol} \mathrm{H}_{2} \mathrm{O}_{2}$ plus $20 \mathrm{mmol}$ pyrogallol as described by Mittler \& Zilinskas (1993). For GPX activity, firstly the gel was washed with $2.5 \%$ triton X-100 for $15 \mathrm{~min}$ and washed twice with distilled water followed by incubation in $10 \mathrm{mmol}$ $\mathrm{K}-\mathrm{PO}_{4}$ buffer $\mathrm{pH} 7.5$ containing $2 \mathrm{mmol} \mathrm{O}$-dianisidine dihydrochloride for $1 \mathrm{hr}$ in darkness. The gel was then incubated for $15 \mathrm{~min}$ in the same buffer containing $0.1 \mathrm{mmol} \mathrm{H}_{2} \mathrm{O}_{2}$ to develop bands against pale yellow background (Kankofer, 2002). For GR gels were immersed in $0.25 \mathrm{~mol}$ tris $/ \mathrm{cl}, \mathrm{pH} 7.5$ containing
$0.24 \mathrm{mmol}$ MTT, $0.4 \mathrm{mmol}$ NADPH, $10 \mathrm{mg}$ DCPIP, $3.4 \mathrm{mmol}$ oxidized glutathione and incubated for $1 \mathrm{hr}$ in dark to develop purple bands (Kang et al., 1999).

\subsection{Statistical Analysis}

The results of in vitro study were given as mean \pm standard deviation (SD) obtained from three independent experiments and analyzed with two-way analysis of variance ANOVA and a " $p$ " value less than $0.05(p<0.05)$ was considered as significantly different from each other.

\section{RESULTS AND DISCUSSION}

\subsection{Growth parameters}

Noteworthy reduction was seen in BRSRT seedling development (shoot length, root length and leaf area) under salt stress. Plants responded to Se treatment in dose dependent manner; $40 \mu \mathrm{mol} \mathrm{Na}_{2} \mathrm{SeO}_{4}$ have a stimulatory impact on development when compared with control plants, while $100 \mu \mathrm{mol} \mathrm{Na}_{2} \mathrm{SeO}_{4}$ alone altogether significantly reduce the tolerance index of root length, shoot length and leaf area by $26.23 \%$,
$50.09 \%$ and $61.5 \%$, respectively over control (Table 1). The maximum tolerance index was obtained in plants treated with $40 \mu \mathrm{mol} \mathrm{Na}_{2} \mathrm{SeO}_{4}$ alone. $40 \mu \mathrm{mol} \mathrm{Se}$ supplementation with $50 \mathrm{mmol}$ and $100 \mathrm{mmol} \mathrm{NaCl}$ concentrations promoted BRSRT seedling growth $(108 \%, \quad 101.1 \%, \quad 110.3 \%$ and $52.87 \%$, $69.20 \%, 79.36 \%)$ respectively. Our results suggest that $40 \mu \mathrm{mol}$ Se has better protective response to different salinity level as compared to control.

Table 1: Stress tolerance Index (STI) of selenium in the form of $\mathrm{Na}_{2} \mathrm{SeO}_{4}$ induced growth parameters (root length, shoot length, leaf area) under salinity stress

\begin{tabular}{|l|l|l|l|l|}
\hline \multicolumn{7}{|c|}{ Selected biometric parameters } \\
\hline \multicolumn{2}{|c|}{ Treatments } & \multicolumn{1}{c|}{ Root length TI } & \multicolumn{1}{c|}{ Shoot length TI } & \multicolumn{1}{c|}{ Leaf area TI } \\
\hline Salt $(\mathrm{mmol})$ & $\mathrm{Se}(\mu \mathrm{mol})$ & $(\%)$ & $(\%)$ & 0 \\
\hline 0 & 0 & 0 & 0 & $114.2 \mathrm{a}$ \\
\hline & 40 & $116 \mathrm{a}$ & $111.2 \mathrm{a}$ & $61.50 \mathrm{e}$ \\
\hline & 100 & $26.23 \mathrm{e}$ & $50.09 \mathrm{e}$ & $104.7 \mathrm{~b}$ \\
\hline 50 & 0 & $86.78 \mathrm{c}$ & $86.06 \mathrm{c}$ & $110.3 \mathrm{a}$ \\
\hline & 40 & $108.0 \mathrm{~b}$ & $101.1 \mathrm{~b}$ & $81.71 \mathrm{c}$ \\
\hline & 100 & $84.57 \mathrm{c}$ & $83.60 \mathrm{c}$ & $65.15 \mathrm{e}$ \\
\hline & 0 & $50.33 \mathrm{~d}$ & $51.63 \mathrm{e}$ & $79.36 \mathrm{c}$ \\
\hline & 40 & $52.87 \mathrm{~d}$ & $69.20 \mathrm{~d}$ & $70.02 \mathrm{~d}$ \\
\hline
\end{tabular}

Values are the mean \pm SD of three replicates in column, and the values in the same column with different letters are significantly different from each other $(p<0.05)$

\subsection{Photosynthetic pigments}

A significant decrease of 0.17 fold \& 0.40 fold in chlorophyll $a$ (Figure 1a), 0.40 fold \& 0.63 fold in chlorophyll $b$ (Figure $1 \mathrm{~b}$ ) and 0.55 fold $\& 0.40$ fold in carotenoids content (Figure 1c), was seen in leaves of BRSRT grown in the medium containing $50 \mathrm{mmol}$ and $100 \mathrm{mmol} \mathrm{NaCl}$ respectively. Whereas the leaves when grown in $40 \mu \mathrm{mol} \mathrm{Na} \mathrm{NaO}_{4}$ alone increased the content of chl $a$ by 0.46 folds, chl $b$ by 0.26 fold and carotenoids by 0.85 fold (Figure 1). However, the addition of $40 \mu \mathrm{mol} \mathrm{Na} \mathrm{NeO}_{4}$ to BRSRT leaves grown in $50 \mathrm{mmol}$ and $100 \mathrm{mmol} \mathrm{NaCl}$ stressed seedlings showed a significant increase of 0.071 fold \& 0.100 fold in chlorophyll $a$ (Figure 1a), 0.25 fold \& 0.31 fold in chlorophyll $b$ (Figure $1 \mathrm{~b}$ ) and 0.68 fold $\& 0.14$ fold in carotenoids content (Figure 1c) as compared to salt treatment alone. 

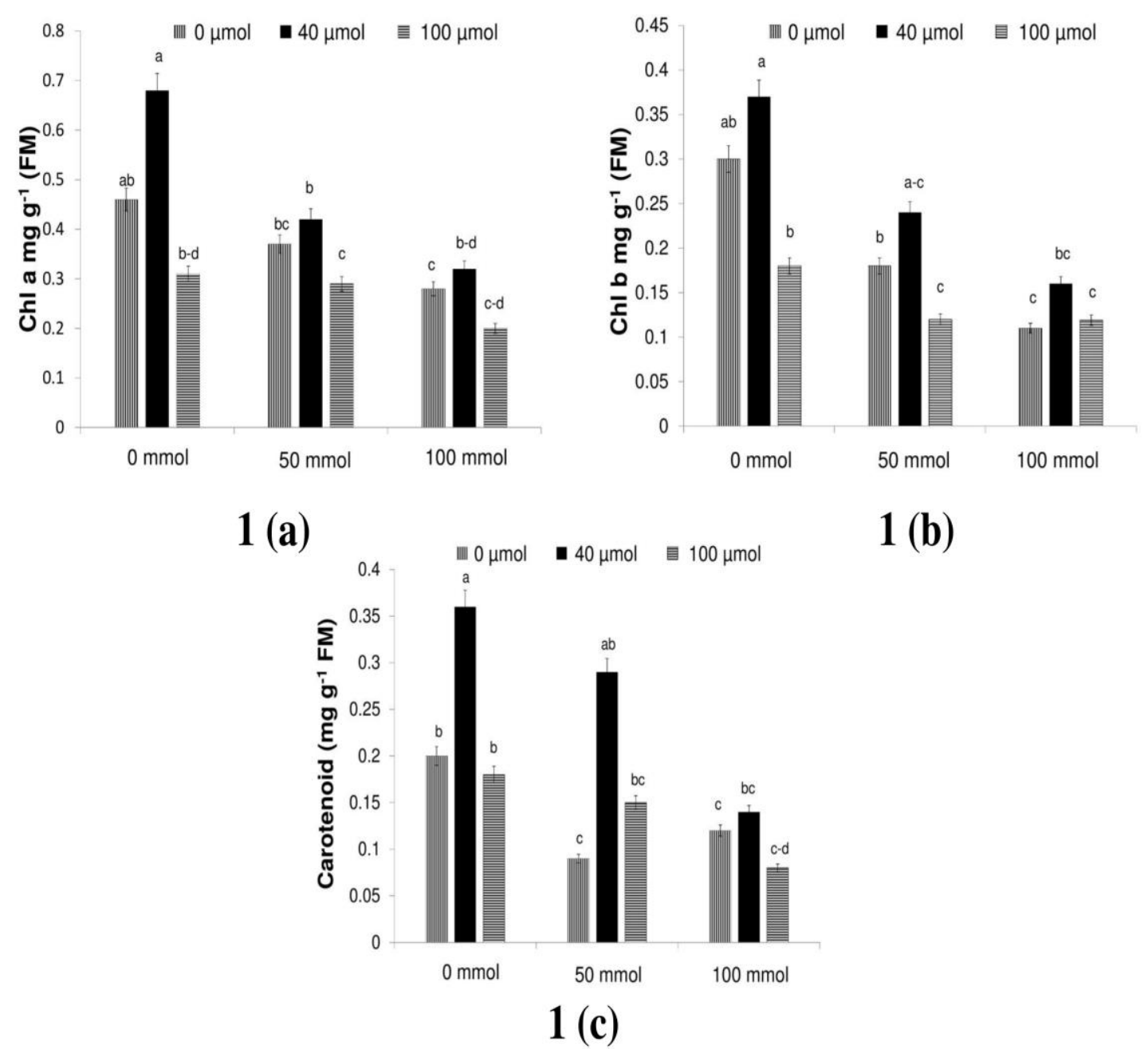

1 (b)

Figure 1: Chlorophyll and carotenoids contents in rapeseed seedlings induced by selenium $\left(\mathrm{Na}_{2} \mathrm{SeO}_{4}\right)$ under salt stress conditions: [a] chlorophyll $a$ [b] chlorophyll $b$ [c] carotenoids content. The mean values $(\mathrm{n}=9)$ with different letters across treatments are significantly different at $p<0.05$.

\subsection{Measurement of ROS generation}

Salt stress prompts accumulation of ROS, which aggravates cell redox homeostasis and results in oxidative harm. $\mathrm{H}_{2} \mathrm{O}_{2}$ content and lipid peroxidation (MDA content) are the oxidative stress indicators in plants. There was an increase in $\mathrm{H}_{2} \mathrm{O}_{2}(1.41$ fold \& 2.99 fold) and MDA content ( 0.70 fold \& 1.5 fold) in $50 \mathrm{mmol}$ and $100 \mathrm{mmol} \mathrm{NaCl}$ stressed plant over control. A $40 \mu \mathrm{mol} \mathrm{Na}_{2} \mathrm{SeO}_{4}$ in combination with $50 \mathrm{mmol}$ and $100 \mathrm{mmol}$ salt in plant demonstrated a decrease in $\mathrm{H}_{2} \mathrm{O}_{2}$ and MDA content (1.21 fold \& 2.0 fold and 0.19 fold \& 0.96 fold) which is less than the control and salt stressed plant (Figure 2). These result demonstrated that $40 \mu \mathrm{mol} \mathrm{Na}_{2} \mathrm{SeO}_{4}$ supplementation shielded BRSRT seedlings from harm by salt stress. 


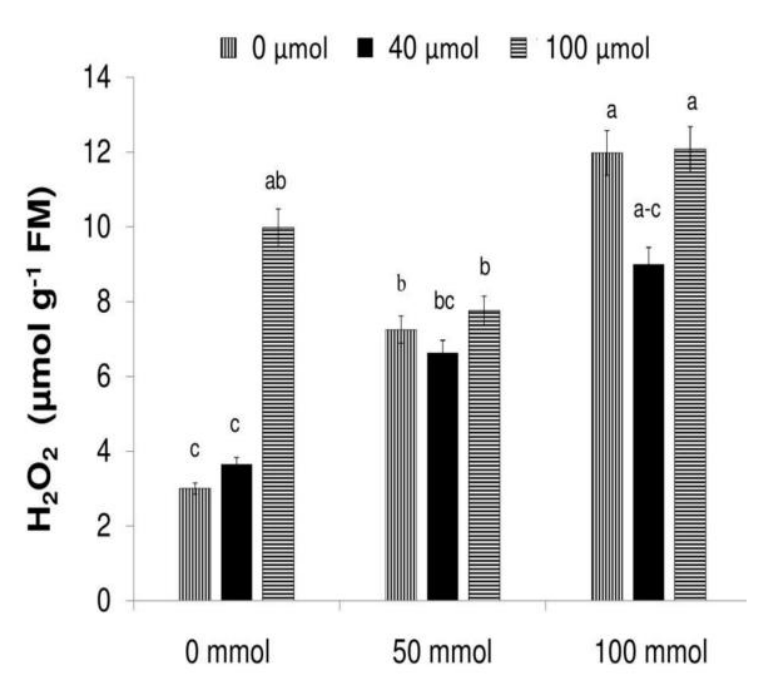

2 (a)

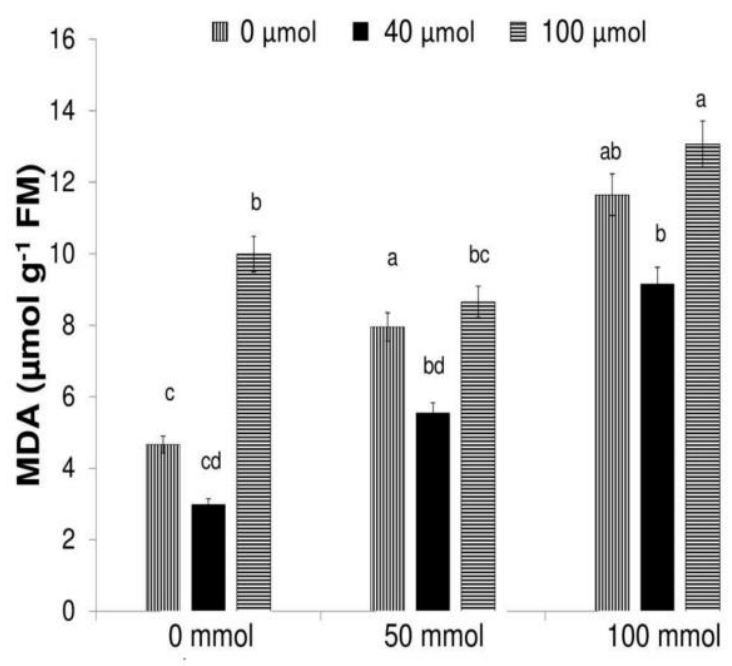

2 (b)

Figure 2: Oxidative stress in BRSRT seedlings: [a] $\mathrm{H}_{2} \mathrm{O}_{2}$ content [b] MDA content. The mean values $(\mathrm{n}=9)$ with different letters across treatments are significantly different at $p<0.05$.

\subsection{Measurements of non-enzymatic antioxidant activity}

Significant reduction ( 0.20 and 0.42 fold $)$ in the AsA content of BRSRT leaves grown in $50 \mathrm{mmol}$ and $100 \mathrm{mmol}$ salt was seen. $40 \mu$ mol $\quad \mathrm{Na}_{2} \mathrm{SeO}_{4}$ supplementation increases the ascorbic acid content by 0.15 and 0.27 fold (Figure 3a), while $100 \mu \mathrm{mol} \mathrm{Na}_{2} \mathrm{SeO}_{4}$ addition significantly increased the AsA content. Se alone is not capable to enhance the AsA content but under salt stress it proves to be beneficial.

Salt stress resulted in increase levels of GSH ( 0.68 and 0.44 fold at 50 and $100 \mathrm{mmol} \mathrm{NaCl}$, respectively) compared to control (Figure 3b). Addition of Se to non treated seedlings did not change the GSH content significantly. However, the addition of $40 \mu \mathrm{mol}$ $\mathrm{Na}_{2} \mathrm{SeO}_{4}$ to BRSRT leaves grown in $50 \mathrm{mmol}$ and $100 \mathrm{mmol}$ salt stressed seedlings resulted in significant increase ( 0.40 and 0.10 fold, respectively) of GSH as compared to the seedling grown without Se. $100 \mu \mathrm{mol}$ $\mathrm{Na}_{2} \mathrm{SeO}_{4}$ did not change the GSH content in both the salt concentration.
Salinity treatments markedly increased the GSSG content in rapeseed seedlings. In our experiment, GSSG level increased by 0.85 and 1.42 fold at 50 and $100 \mathrm{mmol} \mathrm{NaCl}$, respectively (Figure 3c). Se alone did not increase the GSSG content, but, under salt stress, in both $40 \mu \mathrm{mol}$ and $100 \mu \mathrm{mol} \mathrm{Na}_{2} \mathrm{SeO}_{4}$ the levels of GSSG was lower than salt alone.

The GSH/GSSG ratio remained almost unchanged at $50 \mathrm{mmol} \mathrm{NaCl}$, and $100 \mathrm{mmol} \mathrm{NaCl}$ (Figure 3d). However, supplement of $40 \mu \mathrm{mol} \mathrm{Na}_{2} \mathrm{SeO}_{4}$ showed a significant (0.98 and 0.21 fold) increase in the GSH/GSSG ratio, compared to seedlings treated with salt alone.

NPT level at 50 and $100 \mathrm{mmol} \mathrm{NaCl}$ increased by 0.67 and 0.43 fold as compared to control (Figure 3e). Se alone did not change the NPT content. However, under salt stress (50 and $100 \mathrm{mmol}$ ), the seedlings with $40 \mu \mathrm{mol} \mathrm{Na}_{2} \mathrm{SeO}_{4}$ supplement showed a significant ( 0.40 and 0.10 fold) increase in the NPT content, compared to seedlings treated with salt alone. 

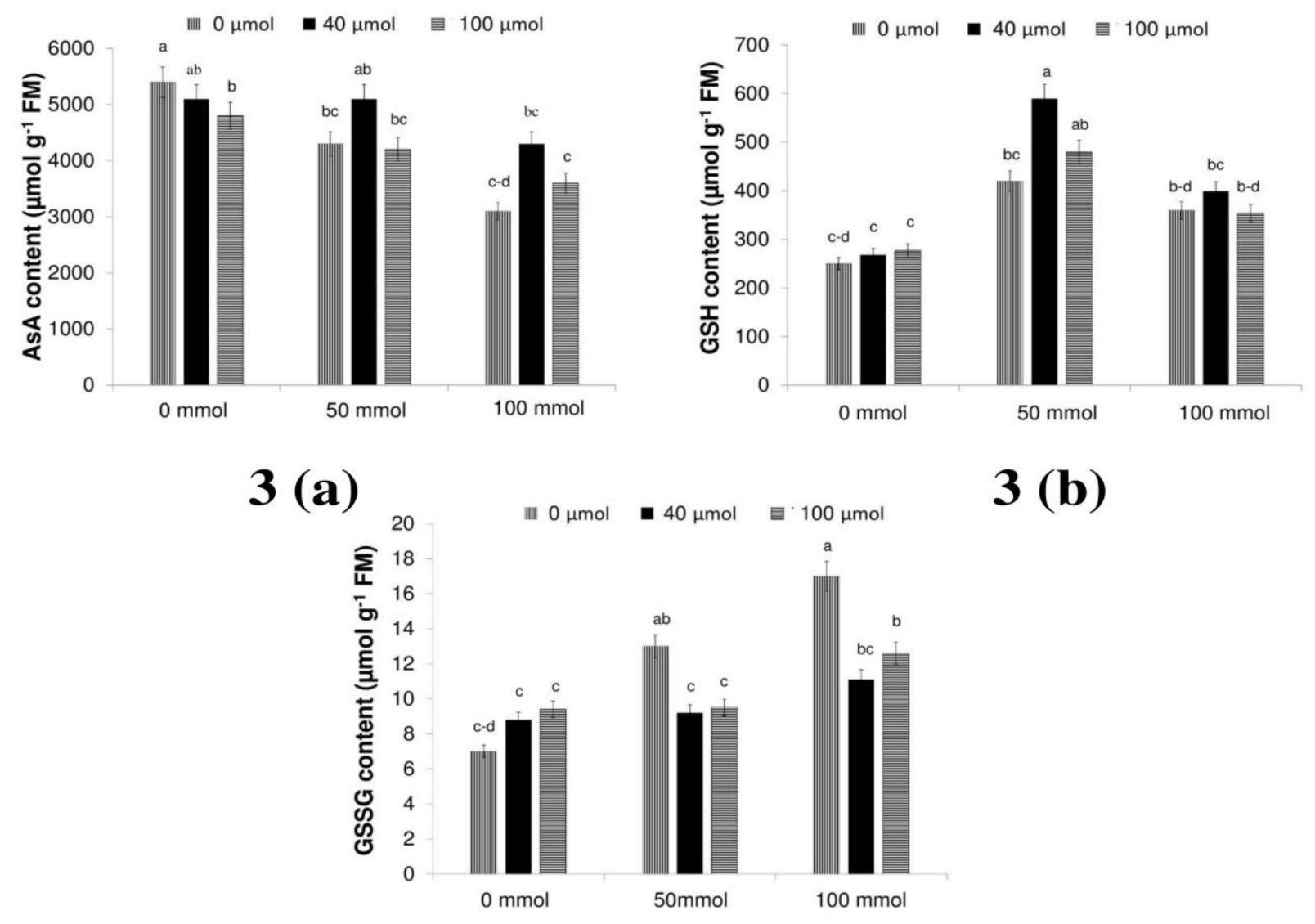

\section{3 (c)}
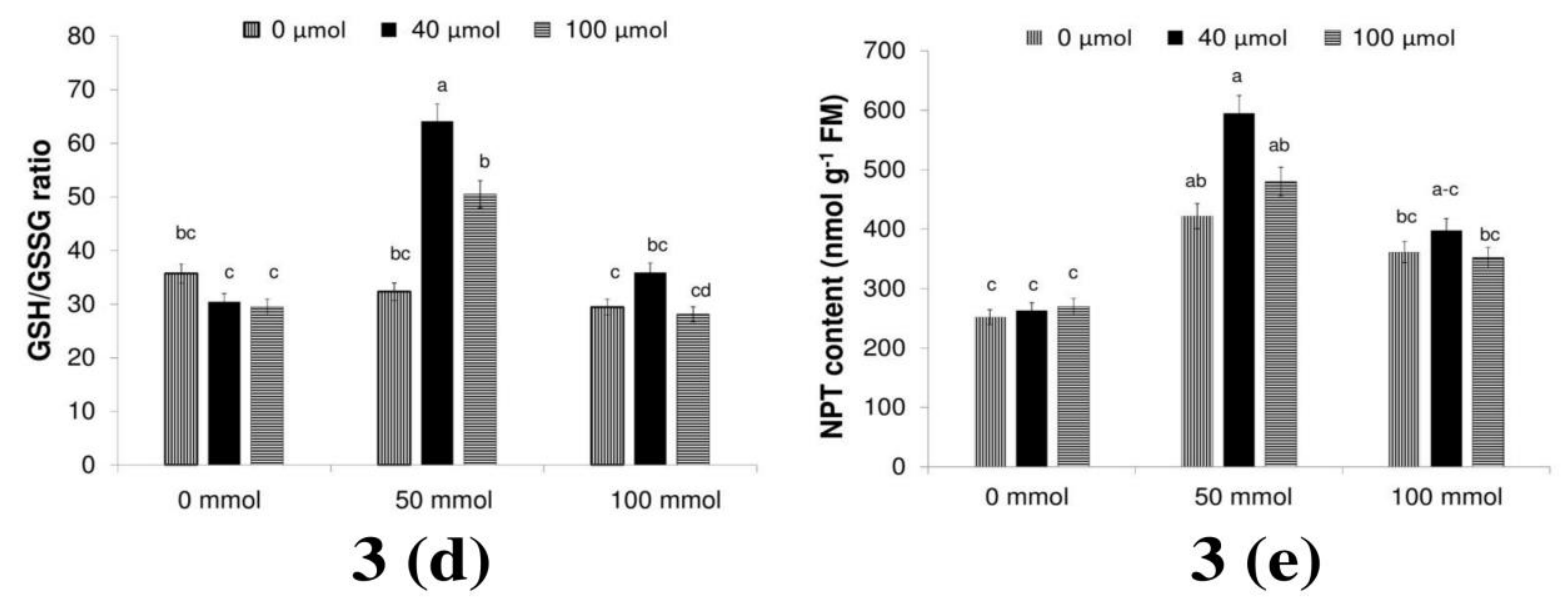

Figure 3: Non enzymatic antioxidant content in rapeseed seedlings induced by selenium $\left(\mathrm{Na}_{2} \mathrm{SeO}_{4}\right)$ under salt stress conditions [a] Reduced Ascorbate (AsA), [b] Reduced Glutathione (GSH), [c] Oxidized Glutathione (GSSG), [d] GSH/GSSG ratio, $[\mathrm{e}]$ Non Protein Thiol $(\mathrm{NPT})$. The mean values $(\mathrm{n}=9)$ with different letters across treatments are significantly different at $p<0.05$.

\subsection{Measurements of enzymatic antioxidant activity}

The effect of different concentrations of $\mathrm{Na}_{2} \mathrm{SeO}_{4}$ treatments on SOD, CAT, APX, GPX \& GR activities in BRSRT leaves, exposed to salt stress are shown in (Figure 4 \& 5).

SOD activity of BRSRT leaves slightly increased at 50 mmol salt stress while at $100 \mathrm{mmol} \mathrm{NaCl}$ stress the 
activity decreased (Figure 4a). 40 and $100 \mu \mathrm{mol}$ $\mathrm{Na}_{2} \mathrm{SeO}_{4}$ alone is incompetent to increase the SOD activity whereas $40 \mu \mathrm{mol} \quad \mathrm{Na}_{2} \mathrm{SeO}_{4}$ supplementation showed a remarkable increase in the SOD activity $(0.87$ and 0.67 fold) at both the salt stress $(50 \mathrm{mmol}$ and 100 mmol). Activity staining of SOD gels shows three oligomeric forms at $40 \mu \mathrm{mol} \quad \mathrm{Na}_{2} \mathrm{SeO}_{4}$ and in combination of $40 \mu \mathrm{mol} \mathrm{Na} \mathrm{Na}_{2} \mathrm{SeO}_{4}$ and $50 \mathrm{mmol} \mathrm{NaCl}$ stress (Figure 5a).
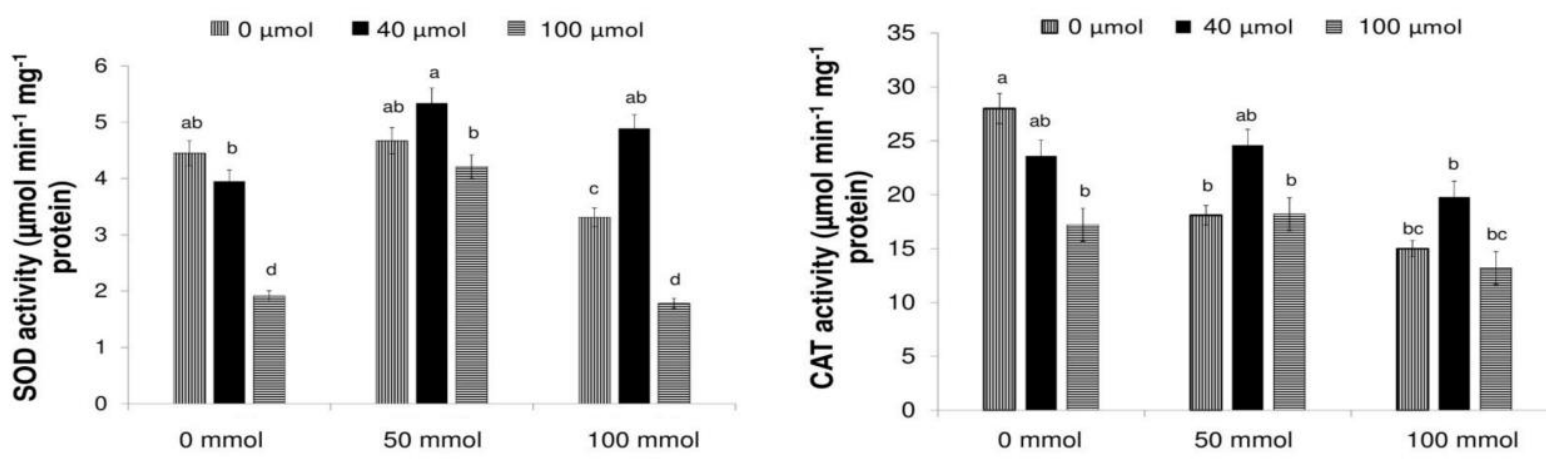

4 (a)

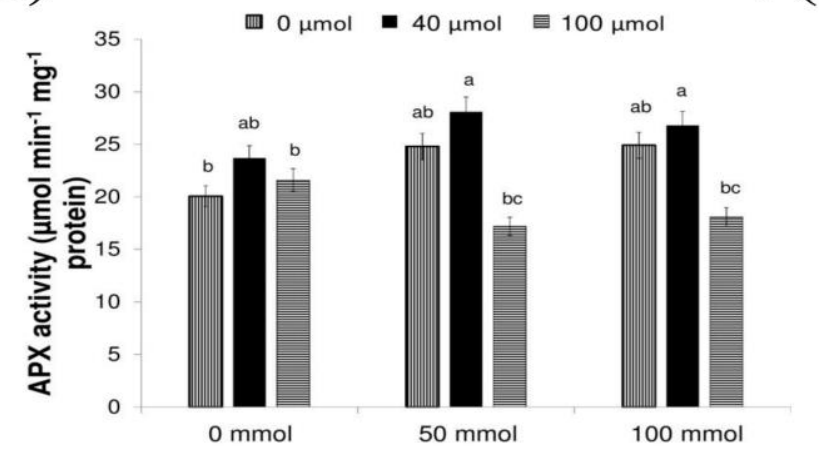

\section{4 (c)}
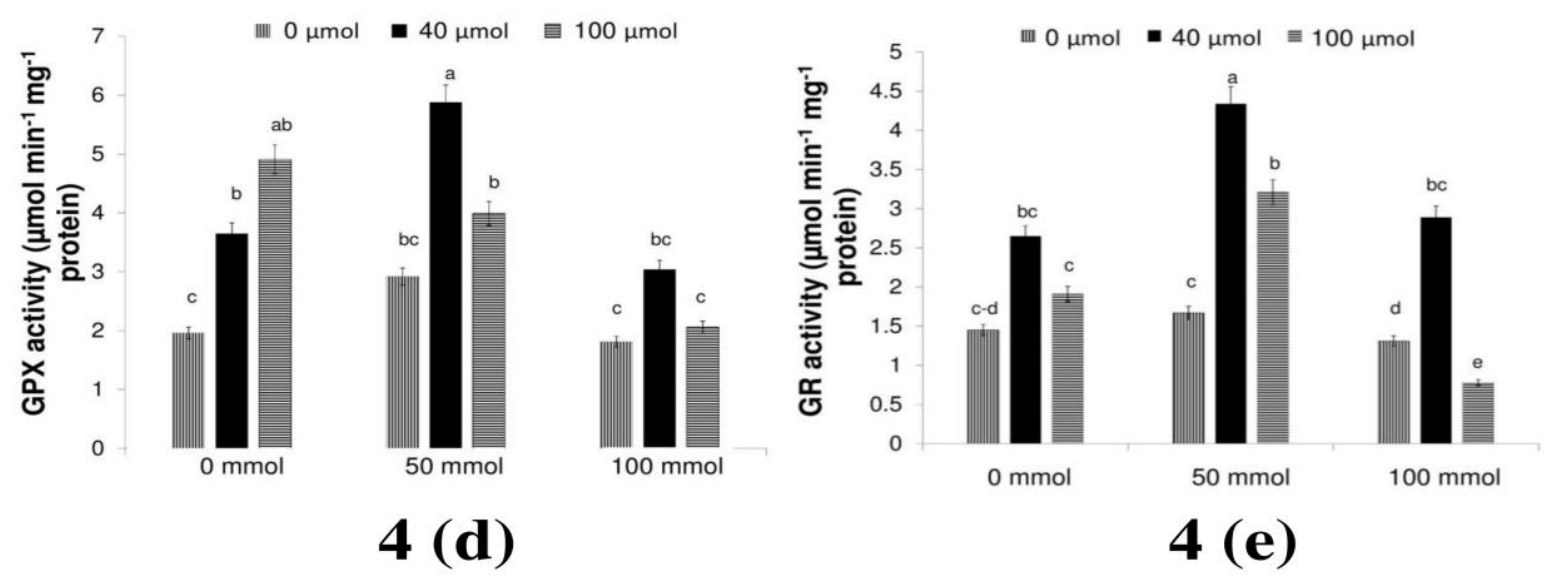

Figure 4: Spectrophotometric analysis of antioxidant enzymes in rapeseed seedlings induced by selenium $\left(\mathrm{Na}_{2} \mathrm{SeO}_{4}\right)$ under salt stress: [a] Superoxide dismutase (SOD), [b] Catalase (CAT), [c] Ascorbate Peroxidase (APX), [d] Glutathione Peroxidase (GPX) [e] Glutathione reductase (GR). The mean values $(n=9)$ with different letters across treatments are significantly different at $p<0.05$. 
CAT activity of BRSRT leaves was 0.35 and 0.46 fold lower at 50 and $100 \mathrm{mmol} \mathrm{NaCl}$ stress (Figure 4b) and impeded with Se treatments alone. However, under 50 and $100 \mathrm{mmol}$ salt stress, the seedlings with $40 \mu \mathrm{mol}$ $\mathrm{Na}_{2} \mathrm{SeO}_{4}$ supplementation demonstrated an increment (0.36 and 0.32 fold) in the CAT activity, compared to seedlings treated with $\mathrm{NaCl}$ alone. $100 \mu \mathrm{mol} \mathrm{Na}_{2} \mathrm{SeO}_{4}$ did not change the CAT activity in both the salt concentration. In-gel assays for detecting CAT activity, revealed three isozymes (CAT 1, CAT 2 and CAT 3)
(Figure 5b). BRSRT leaves treated with $\mathrm{Na}_{2} \mathrm{SeO}_{4}$ and $\mathrm{NaCl}$ alone demonstrated a reduction in total CAT activity as judged by intensities of bands. Salt stress plus $100 \mu \mathrm{mol}$ Se treatments did not create any remarkable effect on total CAT activity. Notwithstanding, both densitometric (Figure 4b) and total enzyme analyses (Figure $5 b$ ) showed that after 40 $\mu$ mol Se in addition to osmotic stress, the BRSRT leaves had a significant increase in CAT activity as compared to separately applied stresses.

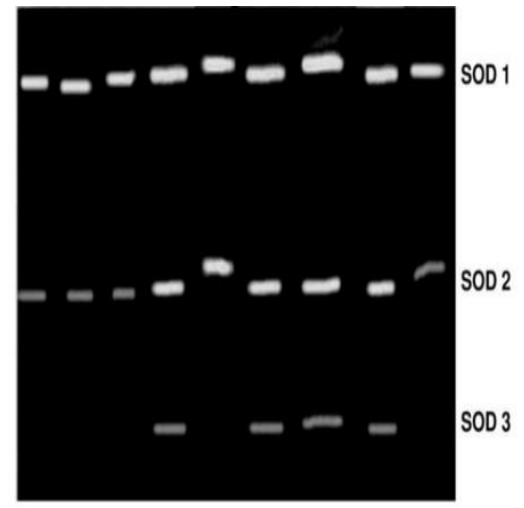

$5(a)$

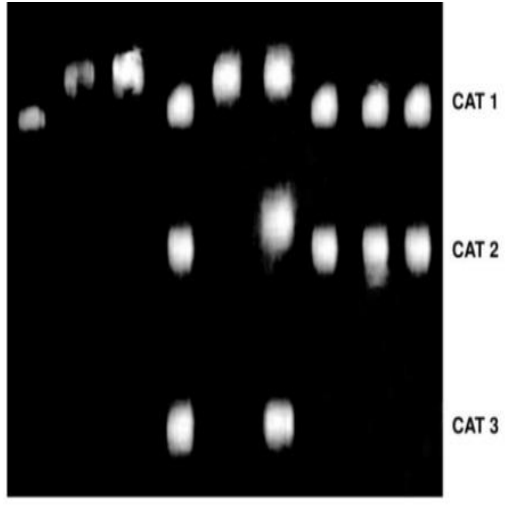

5(b)

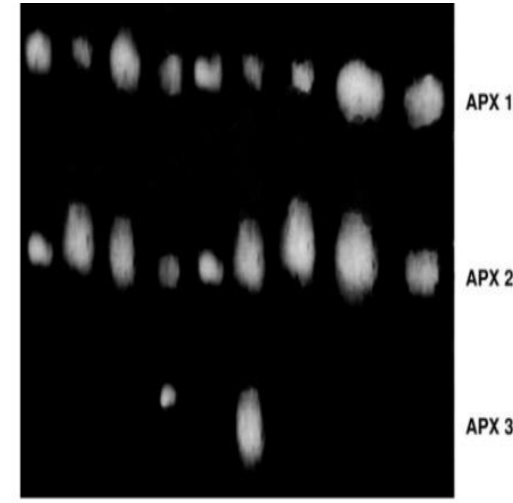

$5(c)$

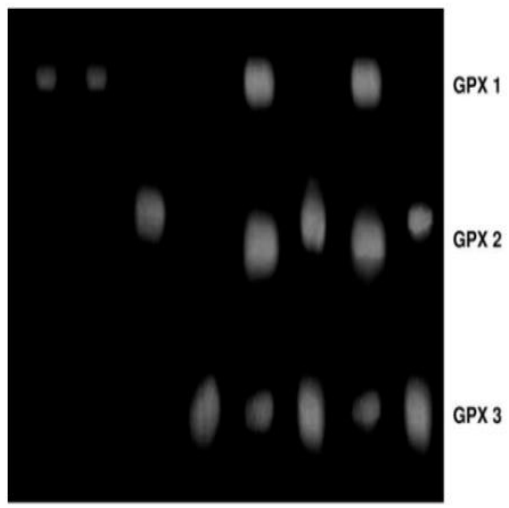

5(d)

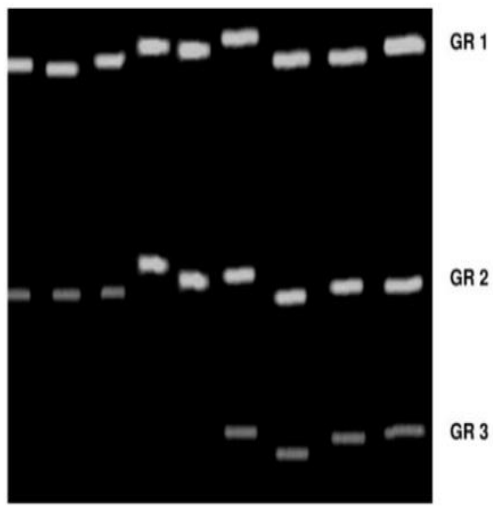

$5(\mathrm{e})$

Figure 5: In-gel visualisation of antioxidant enzymes in rapeseed seedlings induced by selenium $\left.\left(\mathrm{Na}_{2} \mathrm{SeO}\right)_{4}\right)$ under salt stress: [a] Superoxide dismutase (SOD), [b] Catalase (CAT), [c] Ascorbate Peroxidase (APX), [d] Glutathione Peroxidase (GPX), [e] Glutathione reductase (GR). Lane 1 - Control; Lane 2 - $50 \mathrm{mM} \mathrm{NaCl}$ concentration; Lane 3 - $100 \mathrm{mM} \mathrm{NaCl}$ concentration; Lane $4-40 \mu \mathrm{mol} \mathrm{Na}_{2} \mathrm{SeO}_{4}$ concentration; Lane 5- $100 \mu \mathrm{mol}^{\mathrm{Na}} \mathrm{SeO}_{4}$ concentration; Lane 6 - 50 mmol NaCl concentration $+40 \mu \mathrm{mol} \mathrm{Na} \mathrm{SeO}_{4}$ concentration; Lane 7 - $50 \mathrm{mmol} \mathrm{NaCl}$ concentration $+100 \mu \mathrm{mol} \mathrm{Na} \mathrm{SeO}_{4}$ concentration; Lane $8-100$ mmol NaCl concentration $+40 \mu \mathrm{mol} \mathrm{Na}_{2} \mathrm{SeO}_{4}$ concentration; Lane 9 - $100 \mathrm{mmol} \mathrm{NaCl}$ concentration $+100 \mu \mathrm{mol} \mathrm{Na} \mathrm{SeO}_{4}$ concentration. 
In BRSRT seedlings, APX activity increased by 0.26 and 0.24 fold, at 50 and $100 \mathrm{mmol} \mathrm{NaCl}$, respectively, compared to the activity in control (Figure 4c). The application of Se alone did not significantly influence the APX activity but salt-stressed (50 and $100 \mathrm{mmol}$ $\mathrm{NaCl}$ ) seedlings with $40 \mu$ mol $\mathrm{Na}_{2} \mathrm{SeO}_{4}$ supplement showed elevated APX activity (0.15 and 0.06 fold). High intensity bands of APX (APX2 and APX3) were found in presence of $40 \mu \mathrm{mol}$ Se treated plants as shown in Figure 5(c). These results corroborated with the spectrophotometric analysis. However, $100 \mu \mathrm{mol}$ $\mathrm{Na}_{2} \mathrm{SeO}_{4}$ significantly decreased the APX activity and the intensity of bands reduced (Figure 5c) at both high salt and selenium combination.

As compared to control seedlings, the activity of GPX in $50 \mathrm{mmol} \mathrm{NaCl}$ increased (by 0.49 fold), although at $100 \mathrm{mmol}$, it remained unaltered (Figure 4d) as in control plants. However, 50 and $100 \mathrm{mmol}$ salt-stressed seedlings supplemented with $40 \mu \mathrm{mol} \mathrm{Na} \mathrm{NeO}_{4}$ showed a significant (1.01 and 0.68 fold) rise in GPX activity in contrast to seedlings treated with $\mathrm{NaCl}$ alone. $100 \mathrm{mmol}$ salt in addition to $100 \mu \mathrm{mol} \mathrm{Na} \mathrm{NeO}_{4}$ treatments did not make any impact on total GPX activity. The in-gel assay showed high intensity of bands of GPX (GPX1, GPX2, and GPX3) in Figure 5(d) of salt-stressed (50 and $100 \mathrm{mmol}$ ) seedlings supplemented with $40 \mu \mathrm{mol}$ $\mathrm{Na}_{2} \mathrm{SeO}_{4}$.

The activity of GR in $50 \mathrm{mmol} \mathrm{NaCl}$ treated leaves did not increase at $100 \mathrm{mmol}$ (decreases by 0.1 fold) as compared to control plants. Application of $40 \mu \mathrm{mol}$ $\mathrm{Na}_{2} \mathrm{SeO}_{4}$ increases (1.67 and 1.05 fold) at both the salt stressed plants $(50 \mathrm{mmol}$ and $100 \mathrm{mmol} \mathrm{NaCl}$ ) respectively (Figure 4e). $100 \mathrm{mmol}$ salt in addition to $40 \mu \mathrm{mol} \quad \mathrm{Na}_{2} \mathrm{SeO}_{4}$ treatments showed remarkable increment in the GR activity ( 0.98 fold) as compared to $50 \mathrm{mmol} \mathrm{NaCl}$ treated plants. In-gel assays for detecting GR activity, revealed three isozymes (GR1, GR 2 and GR 3) (Figure 5e) in presence of salt and selenium whereas two bands were appeared on the control, salt and $\mathrm{Na}_{2} \mathrm{SeO}_{4}$ treated plants.

\section{DISCUSSION}

Among the diverse abiotic stresses restraining the crop productivity, salinity stress is a foremost problem which needs to be addressed. High salt concentration decreases the osmotic potential of soil solution creating water stress in plants and cause severe ion toxicity (Shabala, 2013). Reduction of photosynthetic pigments during salt stress could be activation of photosynthetic destructive enzymes chlorophyllase (Hashem et al., 2013). It was observed that the chlorophyll content increased significantly with $40 \mu \mathrm{mol} \mathrm{Na} \mathrm{SeO}_{4}$ application which somewhat reduces the damage to the chloroplasts (Figure 1), this is in agreement with the positive effects of Se treatment in delaying the loss of chlorophyll in senescing Vicia faba L. plants (Moussa et al., 2010). Findings of the previous studies have indicated that exogenously applied Se can be favourable for some species of salt-stressed crops (Hawrylak-Nowak, 2009; Walaa et al., 2010; Hasanuzzaman et al., 2011). In our study, high concentration of $\mathrm{Na}_{2} \mathrm{SeO}_{4}$ with $50 \mathrm{mmol}$ and $100 \mathrm{mmol}$ salt lead to reduction of chlorophyll content. Jiang et al. (2017) also observed that high Se concentration aggravated the damage to the photosynthetic system in Zea mays and resulted in decrease in net photosynthetic rate.

$\mathrm{H}_{2} \mathrm{O}_{2}$ performs dualistic role in plants: at low concentrations, it acts as an indicator molecule involved in adaptation to various forms of biotic and abiotic stress, and at high concentrations, it causes oxidative stress in plants (Hu et al., 2012). Tsai et al. (2004) have observed a progressive $\mathrm{H}_{2} \mathrm{O}_{2}$ accumulation in salt- treated $(150 \mathrm{mmol} \mathrm{NaCl})$ roots of rice. A sharp increase in the level of $\mathrm{H}_{2} \mathrm{O}_{2}$ and lipid peroxidation in salt stressed BRSRT seedlings resulted in increased oxidative damage probably due to impairment of the antioxidant defense. However, the presence of $40 \mu \mathrm{mol}$ $\mathrm{Na}_{2} \mathrm{SeO}_{4}$ in salt-stressed seedlings significantly lowered the levels of $\mathrm{H}_{2} \mathrm{O}_{2}$ and MDA compared to salt-stress alone (Figure 2). Se retarded MDA formation also in experiments performed by Djanaguiraman et al. (2005). The growth stimulating effect of Se may be related to its antioxidative function as demonstrated by diminished $\mathrm{H}_{2} \mathrm{O}_{2}$ content lipid peroxidation. This finding is in accordance with Hartikainen et al. (2000) in ryegrass, Xue et al. (2001) in lettuce and Seppanen et al. (2003) in potato.

It is suggested that Se compounds can control production and quenching of reactive oxygen species either directly or indirectly through regulation of antioxidants level (Kaur et al. 2014). AsA can protect membranes by directly scavenging $\mathrm{O}_{2}^{-{ }^{-}}$and $\mathrm{OH}^{--}$. It has been reported that plants with high AsA contents show improved tolerance to oxidative stress (Foyer et al., 1995). In this study, we observed that the level of AsA is decreased when plant is exposed to $50 \mathrm{mmol}$ and 100 $\mathrm{mmol} \mathrm{NaCl}$ stress (Figure 3a). However, addition of 40 $\mu$ mol $\mathrm{Na}_{2} \mathrm{SeO}_{4}$ significantly increased the AsA content in salt-stressed seedlings. In the nonexistence of stress, tissues such as leaves usually maintain measurable GSH/GSSG ratios of approximately 20:1 (Foyer \& Noctor, 2011). Addition of $40 \mu \mathrm{mol} \quad \mathrm{Na}_{2} \mathrm{SeO}_{4}$ 
significantly increased the GSH content in salt-stressed seedlings (Figure 3b). This increased level of GSH in Se-treated leaves might be attributable to Se boosting GSH synthesis. This study is in accordance with Xue et al. (2001), who reported that Se accelerated efficient recycling of GSH, which is based on GR activity. The relationship between Se and GSH synthesis was also reported by Anderson \& McMahon (2001). Similarly, Hasanuzzaman \& Fujita (2011) reported that the GSH content was also enhanced by Se both in droughtstressed rapeseed seedlings. As shown in Figure 3(c), GSSG levels increased in salt-stressed seedlings. This increase might partly attribute to a decrease in the rate of GSH recycling or to an increased rate of degradation (Foyer \& Noctor, 2009). Sumithra et al. (2006) reported that chickpea plants with lower GSSG concentrations possessed a strong antioxidative system and were better protected against oxidative damage during salt-stress conditions. In our experiment, the Se-treated saltstressed seedlings showed lower GSSG level than the seedlings treated with salt alone (Figure 3c). This increase in the GSH/GSSG ratio (Figure 3d) in Sesupplemented salt stressed BRSRT seedlings also provides a clear demonstration of the role of Se towards salt tolerance. Tolerance toward metals correlates well with the level of non-protein thiols which include glutathione, phytochelatins and other SH-rich compounds (Kafel et al., 2010). In the present work treatment of BRSRT leaves with $40 \mu \mathrm{M} \mathrm{Na}_{2} \mathrm{SeO}_{4}$ in salt stress caused a significant increase in proline content compared to untreated plants. This could be due to the effect of Se on proline metabolism enzymes. This was analogous to the study of Nadgórska-Socha et al. (2013) who observed an increment in non-protein -SH group content in leaves of Silene vulgaris (Moench) Garcke populations.

The enhanced SOD activity under salt stress (Figure 4a) in our study is corroborated with the finding of Meloni \& Martińez (2009) in Prosopis ruscifolia Griseb. With the increase in total SOD activity, a concomitant increase in the activities of isoform of SODs (three bands) was observed in response to Se under both the salt stress (Figure 5a). According to Hernandez et al. (2010), Brassica oleracea revealed three bands of SODs under salt stress. The decline in CAT activity is regarded as a general response to many stresses (Liu et al., 2008). It may also be linked with dreadful conditions caused by induced peroxisomal proteases or may be due to the photo-inactivation of the enzyme. On the other hand, CAT activity decreased under salinity stress, similarly as in the experiments of Hasanuzzaman et al. (2011) on rapeseed plants also stated that Se supplementation induced an increase in CAT activity, which indicated a protective role of Se in scavenging $\mathrm{H}_{2} \mathrm{O}_{2}$ under salt stress. However, the CAT activity was restored to the control level after Se supplementation of salt- stressed plants with $40 \mu \mathrm{mol}$ Se in our study (Figure 4b). APX activity increased in accordance with earlier observation of Mittal et al. (2012) in Brassica juncea (L.) Vassilii Matveievitch Czernajew. The addition of $40 \mu \mathrm{mol}$ Se to the medium containing $50 \mathrm{mmol}$ and 100 mmol salt increased APX activity as compared to the salt exposed plants without selenium (Figure 4c). In accordance with Salekjalali et al. (2012), six bands of APX were present in the drought stressed barley plants. Moreover addition of $40 \mu \mathrm{mol}$ Se to salt stressed BRSRT leaves, revealed three isozymes with enhanced intensity (Figure 5c).

One of the likely candidates responsible for $\mathrm{H}_{2} \mathrm{O}_{2}$ detoxification and eventually lowering of lipid peroxidation from cellular $\mathrm{H}_{2} \mathrm{O}_{2}$ pool in high salt and $\mathrm{Se}$ stress could be the GPX antioxidant system. In our study, since there is no significant increase in GPX activity in BRSRT leaves, subjected to salt stress, it was not sufficient to detoxify the $\mathrm{H}_{2} \mathrm{O}_{2}$ radicals, as is also reported in Yildiztugay et al. (2016). Moreover, the application of selenium to salt treated BRSRT leaves, brought about significant increase in the GPX activity (Figure 4d). In accordance with Diao et al. (2014), the amplification in enzyme activity may be due to Sedependent GPX. GPX isoform pattern was strongly affected by salt stress in combination with $40 \mu \mathrm{mol}$ Se, at which new isozymes designated as GPX 2 and GPX 3 appeared. The activities of other isoform GPX 1 were enhanced as compared to control (Figure 5d). GPX was more efficient in destroying $\mathrm{H}_{2} \mathrm{O}_{2}$ than was catalase under salt stress, since Se could not increase the catalase activity in a significant manner. The reason for this could be that GPX, which is present throughout the cell and has higher substrate affinity in the presence of glutathione as a reductant (Foyer \& Noctor, 2009) and CAT is present only in the peroxisomes and has low substrate affinity, as it requires simultaneous access of two molecules of $\mathrm{H}_{2} \mathrm{O}_{2}$ (Filek et al., 2008). GR catalyses the NADPH-dependent reduction of the disulphide bond of GSSG, and is, therefore, important for maintaining the GSH pool. The present study showed high GR activity on Se addition under salt stress (Figure 4e) which is in accordance with the study of Hoque et al. (2007). This increase in the activity of GR contributes to the maintenance of a high GSH/GSSG ratio which is beneficial for GSH dependent enzymes involved in the antioxidant defense. The increase in the GR activity upon Se treatment also resulted in the accumulation of GSH, and ultimately, conferred salt tolerance in plants. 


\section{CONCLUSION}

The present study provides an insight into the role of Se in regulating of biochemical responses to salt stress. It was observed that $40 \mu \mathrm{mol} \mathrm{Na}_{2} \mathrm{SeO}_{4}$ treatment in BRSRT seedlings enhanced protective role of $\mathrm{Se}$ in ROS detoxification system protection against high saltstressed oxidative damage, as indicated by the down regulation of lipid peroxidation and $\mathrm{H}_{2} \mathrm{O}_{2}$ levels. The components of the antioxidant defense system machinery are upregulated in the presence of Se, which allowed the plants to cope better with salt stress. Based on our results and the results found in the literature, we conclude that the non-enzymatic and enzymatic antioxidant system are simultaneously regulated to control the levels of ROS during salt stress and to maintain redox homeostasis to increase plant survival.

\section{ACKNOWLEDGEMENT}

The author thanks the Head, Department of P.G. Studies and Research in Biological Sciences, R. D. University, Jabalpur, for providing laboratory facilities. Financial support for this work was supported by National
Fellowship for Other Backward Class (OBC), University Grants Commission, New Delhi, for financial assistance F./2014-15/NFO -2014-15-OBCCHH-1655/ (SA-III/Website).

\section{REFERENCES}

Aebi, H. (1984). Catalase in vitro. Methods in Enzymology, 105, 121-126, doi:10.1016/S00766879(84)05016-3

Aliu, S., Rusinovci, I., Fetahu, S., Gashi, B., Simeonovska, E., Rozman, L. (2015). The effect of salt stress on the germination of maize (Zea mays L.) seeds and photosynthetic pigments. Acta Agriculturae Slovenica, 105(1), 85-94, doi:10.14720/aas.2015.105.1.09

Anderson, M.E. (1985). Determination of glutathione and glutathione disulfide in biological samples. Methods in Enzymology, 113, 548-555, doi:10.1016/S0076-6879(85)13073-9

Anderson, J.W., \& McMahon, P.J. (2001). The role of glutathione in the uptake and metabolism of sulfur and selenium. In: Grill D, Tausz MM, de Kok LJ (eds) Significance of glutathione to plant adaptation to the environment. Kluwer Academic, The Netherlands, 57-99. doi:10.1007/0-306-47644-4_4

Apel, K., \& Hirt, H. (2004). Reactive oxygen species: metabolism, oxidative stress, and signal transduction. Annual Review of Plant Biology, 55, 373-399,

doi:10.1146/annurev.arplant.55.031903.141701

Arnon, D.I. (1949). The conversion of light into chemical energy in photosynthesis. Nature, 184, 10-21, doi:10.1038/184010a0

Avila, F.W., Yang, Y., Faquin, V., Ramos, S.J., Guilherme, L.R., Thannhauser, T.W. (2014). Impact of selenium supply on Semethylselenocysteine and glucosinolate accumulation in selenium-bio fortified Brassica sprouts. Food Chemistry, 165, 578-586, doi:10.1016/j.foodchem.2014.05.134

Cakmak, I., Strbac, D., Marschner, H. (1993). Activities of hydrogen peroxide scavenging enzymes in germinating wheat (Triticum aestivum L.) seeds. Journal of Experimental Botany, 44, 127-132, doi: 10.1093/jxb//44.1.127.

Diao, M., Ma, L., Wang, J., Cui, J., Fu, A., Liu, H. (2014). Selenium promotes the growth and photosynthesis of tomato (Lycopersicon esculentum Miller) seedlings under salt stress by enhancing chloroplast antioxidant defense system. Journal of Plant Growth Regulation, 33, 671-682, doi:10.1007/s00344-014-9416-2

Djanaguiraman, M., Devi, D.D., Shanker, A.K., Sheeba, J.A., Bangarusamy, U. (2005). Selenium - an antioxidative protectant in soybean (Glycine max (L). merr.) during senescence. Plant Soil, 272, 7786, doi:10.1007/s11104-004-4039-1

Djanaguiraman, M., Prasad, P.V.V., Seppänen, M. (2010). Selenium protects sorghum leaves from oxidative damage under high temperature stress by enhancing antioxidant defense system. Plant Physiology and Biochemistry, 48 (12), 999-1007, doi:10.1016/j.plaphy.2010.09.009

Elia, A.C., Galarini, R., Taticchi, M.I., Dorr, A.J.M., Mantilacci, L. (2003). Antioxidant responses and bioaccumulation in Ictalurus melas under mercury exposure. Ecotoxicology and Environmental Safety. 55, 162-167. doi:10.1016/S0147-6513(02)00123-9

FAO. (2009). High level expert forum - how to feed the world in 2050. Economic and Social Development

Acta agriculturae Slovenica, 109 - 3, december 2017 
Department, Food and Agricultural Organization of the United Nations, Rome.

Feng, R., Wei, C., Tu, S. (2013). The roles of selenium in protecting plants against abiotic stresses. Environmental and Experimental Botany, 87, 5868, doi:10.1016/j.envexpbot.2012.09.0020

Filek, M., Keskinen, R., Hartikainen, H., Szarejko, I., Janiak, A., Miszalski, Z., Golda, A. (2008). The protective role of selenium in rape (Brassica napus L.) seedlings subjected to cadmium stress. Journal of Plant Physiology, 165, 833-844, doi:10.1016/j.jplph.2007.06.006

Foyer, C.H., \& Noctor, G. (2011). Ascorbate and Glutathione: The Heart of the Redox Hub. Plant Physiology, 155, 2-18, doi:10.1104/pp.110.167569

Foyer, C.H., \& Noctor, G. (2009). Redox Regulation in Photosynthetic Organisms: Signaling, Acclimation, and Practical Implications. Antioxidant and Redox Signaling, 11(4), 861-905, doi:10.1089/ars.2008.2177

Foyer, C.H., Souriau, N., Perret, S., Lelandais, M., Kunert, K.J., Pruvost, C., Jouanin L. (1995). Overexpression of glutathione reductase but not glutathione synthetase leads to increases in antioxidant capacity and resistance to photoinhibition in poplar (Populus tremula; Populus alba) trees. Plant Physiology, 109, 10471057, doi:10.1104/pp.109.3.1047

Giannopolitis, C.N., \& Reis, S.K. (1997). Superoxide dismutase I Occurrence in higher plants. Plant Physiology. 59, 309-314, doi: 10.1104/pp.59.2.

Hajiboland, R., Sadeghzadeh, N., Sadeghzadeh, B. (2014). Effect of Se application on photosynthesis, osmolytes and water relations in two durum wheat (Triticum durum L.) genotypes under drought stress. Acta Agriculturae Slovenica, 103(2), 167179, doi: 10.14720/aas.2014.103.2.2.

Hajiboland, R., \& Amjad L. (2007). Does antioxidant capacity of leaves play a role in growth response to selenium at different sulfur nutritional status? Plant Soil Environment, 53, 207-215. doi:10.14720/aas.2014.103.2.2

Hartikainen, H., Xue, T.L., Piironen, V. (2000). Selenium as an anti-oxidant and pro-oxidant in ryegrass. Plant and Soil, 225, 193-200, doi:10.1023/A:1026512921026

Hashem, A.H., Raifa, A.H., Bekheta, A.M., El-Kady, A.F. (2013). Protective role of Selenium in Canola (Brassica napus L.) plant subjected to salt stress. Egyptian Journal of Experimental Biology (Botany). 9(2), 199-211.
Hasanuzzaman, M., Hossain, M.A., Fujita, M. (2011). Selenium-induced up regulation of the antioxidant defense and methylglyoxal detoxification system reduces salinity-induced damage in rapeseed seedlings (Brassica napus L.). Biological Trace Element Research, 143(3), 1704-1721. doi:10.1007/s12011-011-8958-4

Hasanuzzaman, M., \& Fujita, M. (2011). Selenium pretreatment upregulates the antioxidant defense and methylglyoxal detoxification system and confers enhanced tolerance to drought stress in rapeseed (Brassica napus L.) seedlings. Biological Trace Element Research, 143, 1758-1776, doi:10.1007/s12011-011-8998-9

Hawrylak-Nowak, B. (2009). Beneficial effects of exogenous selenium in cucumber seedlings subjected to salt stress. Biological Trace Element Research, 132 (1), 259-269, doi:10.1007/s12011009-8402-1

Hernandez, M., Fernandez-Garcia, N., Diaz-Vivancos, P., Olmos, E. (2010). A different role for hydrogen peroxide and the antioxidative system under short and long salt stress in Brassica oleracea roots. Journal of experimental Botany,61, 521-535, doi:10.1093/jxb/erp321

Hoagland, D.R., \& Arnon, D.I. (1950). The waterculture method for growing plant without soil. California Agriculture Experiment Station Circular, 347, 1-32.

Hodges, D., Mark John, M., De Long Charles F., Forney, Robert K.P. (1999). Improving the thiobarbituric acid-reactive-substances assay for estimating lipid peroxidation in plant tissues containing anthocyanin and other interfering compounds. Planta, 207, 604-611, doi:10.1007/s004250050524

Hoque, M.A., Okuma, E., Banu, M.N.A., Nakamura, Y., Shimoishi, Y., Murat, Y. (2007). Exogenous proline mitigates the detrimental effects of salt stress more than exogenous betaine by increasing antioxidant enzyme activities. Journal of Plant Physiology, 164, 553-561, doi:10.1016/j.jplph.2006.03.010

Hu, L., Huang, Z., Liu, S., Fu, J. (2012). Growth response and gene expression in antioxidant-related enzymes in two bermudagrass (Cynodon dactylon) genotypes differing in salt tolerance. Journal of the American Society for Horticultural Science, 137, 134-143.

Israr, M., Sahi, S.V., Jain, J. (2006). Cadmium Accumulation and Antioxidative Responses in the Sesbania drummondii callus. Archives of 
Environmental and Contamination Toxicology, 50, 121-127. doi:10.1007/s00244-005-5029-x

Jaleel, C.A., Riadh, K., Gopi, R., Manivannan, P., Inés, J., Al-Juburi, H.J., Zhao, C.X., Shao, H.B., Panneerselvam, R. (2009). Antioxidant defense responses: physiological plasticity in higher plants under abiotic constraints. Acta Physiologiae Plantarum, 31, 427-436, doi:10.1007/s11738-0090275-6

Janmohammadi, M., Abbasi, A., Sabaghnia, N. (2011). Influence of $\mathrm{NaCl}$ treatments on growth and biochemical parameters of castor bean (Ricinus communis L.). Acta Agriculturae Slovenica, 99(1), 31-40, doi:10.2478/v10014-012-0004-5

Jiang, C., Zu, C., Lu, D., Zheng, Q., Shen, Jia., Wang, H., Li, D. (2017). Effect of exogenous selenium supply on photosynthesis, $\mathrm{Na}^{+}$accumulation and antioxidative capacity of maize (Zea mays L.) under salinity stress. Scientific Reports, 7, 42039, doi:10.1038/srep42039

Kafel, A., Nadgórska-Socha, A., Gospodarek, J., Babczyńska, A., Skowronek, M., Kandziora M., Rozpendek, K. (2010). The effects of Aphis fabae infestation on the antioxidant response and heavy metal content in field grown Philadelphus coronarius plants. Science of the Total Environment, 408(5), 1111-1119, doi:10.1016/j.scitotenv.2009.11.013

Kang, K.S., Lim, C.J., Han, T.J., Kim, J.C., Jin, C.D. (1999). Changes in the isozyme composition of antioxidant enzymes in response to aminotriazole in leaves of Arabidopsis thaliana. Journal of Plant Biology, 42, 187-193. doi:10.1007/BF03030477

Kankofer, M. (2002). Superoxide dismutase and glutathione peroxidase activities in bovine placenta: spectrophotometric and electrophoretic analysis. Revue de Médecine Vétérinairé, 153, 121-124.

Kaur, N., Sharma, S., Kaur, S., Nayyar, H. (2014). Selenium in agriculture: a nutrient or contaminant for crops?. Archives of Agronomy and Soil Science, 60 , doi:10.1080/03650340.2014.918258

1593-1624,

Kumar, D. 1995. Salt tolerance in oilseed Brassicaspresent status and future prospects. Plant breeding Abstracts. 65(10), 1439-1477.

Laemmli, U.K. (1970). Cleavage of structural proteins during the assembly of the head of bacteriophage T4. Nature, 227, 680-685, doi:10.1038/227680a0

Liu J., Xie X., Du J., Sun J., Bai X. (2008). Effects of simultaneous drought and heat stress on Kentucky bluegrass (Poa pratensis L.). Journal of
Horticultural Sciences, 115, 190-195, doi:10.1016/j.scienta.2007.08.003

Lowry, H., Rosebrough, J., Farr, A.L., Randall, R.J. (1951). Protein measurement with the Folin phenol reagent. Journal of Biological Chemistry, 193, 265275, doi:10.1038/227680a0

Meloni, D.A., \& Martińez, C.A. (2009). Glycinebetaine improves salt tolerance in vinal (Prosopis ruscifolia Griesbach) seedlings. Brazilian Journal of Plant Physiology, 21, 233-241, doi:10.1590/S167704202009000300007

Mittal, S., Kumari, N., Sharma, V. (2012). Differential response of salt stress on Brassica juncea: Photosynthetic performance, pigment, proline, D1 and antioxidant enzymes. Plant Physiology and Biochemistry, 54, 17-26, doi:10.1016/j.plaphy.2012.02.003

Mittler, R., \& Zilinskas, B.A. (1993). Detection of ascorbate peroxidase activity in native gels by inhibition of the ascorbate- dependent reduction of nitroblue tetrazolium. Analytical Biochemistry, 212, 540-546, doi:10.1006/abio.1993.1366

Moussa, H.R., El-Fatah, A., Ahmed, M. (2010). Protective role of selenium on development and physiological responses of Vicia faba. International Journal of Vegetable Science, 16, 174-183, doi:10.1080/19315260903375137

Mukherjee, S.P., \& Choudhuri, M.A. (1983). Implications of Water Stress-Induced Changes in the Leaves of Endogenous Ascorbic Acid and Hydrogen peroxide in Vigna Seedlings. Physiologia Plantarum, 58, 166-170, doi: 10.1111/j.13993054.1983.tb04162.

Nadgórska-Socha, A., Kafel, A., Kandziora-Ciupa, M., Gospodarek, J., Zawisza-Raszka, A. (2013). Accumulation of heavy metals and antioxidant responses in Vicia faba plants grown on monometallic contaminated soil. Environmental Science and Pollution Research, 20, 1124-1134, doi: 10.1007/s11356-012-1191-7x.

Nakano, Y., \& Asada, K. (1981). Hydrogen peroxide is scavenged by ascorbate specific peroxidase in spinach chloroplasts. Plant and Cell Physiology, 22 , 867-880, doi:10.1093/oxfordjournals.pcp.a076232

Pilon-smits, E.A.H., Hwang, S., Lytle, C.M., Zhu, Y., Tai, J.C., Bravo, R.C., Chen, Y., Leustek, T., Terry, N. (1999). Overexpression of ATP sulfurylasein Indian mustard leads to increased selenate uptake, reduction, and tolerance. Plant Physiology, 119, 123-132, doi:10.1104/pp.119.1.123. 
Poblaciones, M.J., Rodrigo, S., Santamaria, O., Chen, Y., McGrath, S.P. (2014). Selenium accumulation and sepeciationin biofortified chickpea (Cicer arietinum L.) under Mediterrenean conditions. Journal of the Science of Food and Agriculture, 94(6), 1101-1106, doi:10.1002/jsfa.6372

Salekjalali, M., Haddad, R., Jafari, B. (2012). Effects of soil water shortages on the activity of antioxidant enzymes and the contents of chlorophylls and proteins in barley. American-Eurasian Journal of Agricultural \& Environmental Sciences. 12, 57-63.

Seppänen, M., Turakainen, M., Hartikainen, H. (2003). Selenium effects on oxidative stress in potato. Plant Science, $\quad 165, \quad 311-319 . \quad$ doi:10.1016/S01689452(03)00085-2

Shabala, S. (2013). Learning from halophytes: physiological basis and strategies to improve abiotic stress tolerance in crops. Annals of Botany, 112, 1209-1221, doi:10.1093/aob/mct205

Sumithra, K., Jutur, P.P., Carmel B.D., Reddy A.R. (2006). Salinity-induced changes in two cultivars of Vigna radiata: Responses of antioxidative and proline metabolism. Plant Growth Regulation, 50, 11-22, doi:10.1007/s10725-006-9121-7

Tavakkoli, E., Rengasamy, P., McDonald, G.K. (2010). High concentrations of $\mathrm{Na}^{+}$and $\mathrm{Cl}^{-}$ions in soil solution have simultaneous detrimental effects on growth of faba bean under salinity stress. Journal of Experimental Botany, 61, 4449-4459, doi:10.1093/jxb/erq251

Terry, N., Zayed, A.M., De Souza, M.P., Tarun, A.S. (2000). Selenium in higher plants. Annual Review of Plant Physiology and Plant Molecular Biology, 51, 401-432, doi:10.1146/annurev.arplant.51.1.401

Tsai, Y.C., Hong, C.Y., Liu, L.F., Kao, C.H. (2004). Relative importance of $\mathrm{Na}^{+}$and $\mathrm{Cl}^{-}$in $\mathrm{NaCl}-$ induced antioxidant systems in roots of rice seedlings. Physiologia Plantarum, 122, 86-94, doi:10.1007/s11738-016-2191-x
Walaa, A.E., Shatlah, M.A., Atteia, M.H., Sror, H.A.M. (2010). Selenium induces antioxidant defensive enzymes and promotes tolerance against salinity stress in cucumber seedlings (Cucumis sativus L). Arab Universities Journal of Agricultural Sciences, $18,65-76$.

Wang, Y.D., Wang, X., Wong, Y.S. (2012). Proteomics analysis reveals multiple regulatory mechanisms in response to selenium in rice. Journal of Proteomics, 75, 184-1866. doi:10.1016/j.jprot.2011.12.030

Woodbury, W., Spencer, A.K., Stahmann, M.A. (1971). An improved procedure using ferricyanide for detecting catalase isozymes. Analytical Biochemistry, 44, 301-305, doi:10.1016/00032697(71)90375-7

Xue, T.L., Hartikainen, H., Piironen, V. 2001. Antioxidative and growth-promoting effect of selenium on senescing lettuce. Plant and Soil, 237, 55-61. doi:10.1023/A:1013369804867

Yildiztugay, E., Ozfidan-Konakci, C., Kucukoduk, M., Tekis, S.A. (2016). The impact of selenium application on enzymatic and non-enzymatic antioxidant systems in Zea mays roots treated with combined osmotic and heat stress. Archives of Agronomy and Soil Science, 63, 261-275, doi:10.1080/03650340.2016.1201810

Yen, H.C., Oberley, T.D., Vichitbandha, S., Ho, Y.S., St. Clair, D.K. (1996). The protective role of manganese superoxide dismutase against adriamycin-induced acute cardiac toxicity in transgenic mice. The Journal of Clinical Investigation, 98(5), 1253, doi:10.1172/JCI118909

Yu, C.W., Murphy, T.M., Lin, C.H. (2003). Hydrogen peroxide-induces chilling tolerance in mung beans mediated through ABA-independent glutathione accumulation. Functional Plant Biology, 30, 955963, doi:10.1071/FP03091 